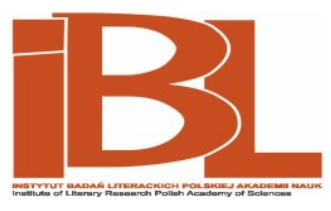

\title{
A War of Shames
}

\author{
Przemysław Czapliński
}




\section{A War of Shames}

DOI:10.18317/td.2018.en.1.5

ctober 25, 2015, just after the early results of that day's parliamentary elections were announced, the leader of the victorious Law and Justice (PiS) party stated: "[...] never again will we have to be ashamed [...]."1

Less than two months later, Polish President Andrzej Duda stated at the official ceremonies marking the 45th anniversary of the events of December 1970: "[...] we are ashamed of the Third Republic of Poland for its inability to prosecute after 1989 the perpetrators of these crimes. We are simply ashamed, nothing less. I think I speak for

1 MK, "Prezes PiS: Panie Prezydencie, melduję wykonanie zadania!," Gazeta Wyborcza, October 25, 2015, accessed March 15, 2016, http://wiadomosci.gazeta.pl/wiadomosci/1,147565,19085077, wybory-parlamentarne-2015-relacja-live-ze-sztabow-wyborczych.html/. "Let me be clear: the law will be enforced. We will pursue the truth. But there will be no revenge, no negative emotions, no personal politics, no retribution, no kicking people while they're down, even if it's their own fault and they deserved to fall. [...] We have to show everyone that public life in Poland can be different, that it can be something to be proud of. That we'll never have to be ashamed in front of those young people sitting in the Sejm gallery, witnessing what's going on down there. And we've been ashamed on more than one occasion, through no fault of our own."

\section{Przemysław \\ Czapliński -}

historian of literature, essayist, translator,

literary critic,

co-founder of the

Department

of Anthropology

of Literature (Adam

Mickiewicz University

in Poznań, Poland).

Recent books: Polska

do wymiany [Poland

to Exchange] (2009),

The Remnants

of Modernity (2015),

Poruszona mapa

(2016) [The Shifted

Map]. Editor of many

collective books -

lately: anthology

Literatura ustna (2011)

[Oral Literature],

Kamp. Antologia

przekładów (2013)

[Camp. Anthology

of Translations]. 
everyone gathered here today. [...] We are ashamed for this Third Republic, in which communist criminals (and some of them were criminals) were lauded as heroes. [...] We are ashamed for this Third Republic, in which most of those responsible for 1970 were accorded state funerals with full military honors. Shame. It is no less than shameful."2

The president also promised that history would be restarted, and that the year 2015 would be a new 1989, done properly this time. Yet the more the two speakers emphasized the difference between the "former" and "future" Poland, the more apparent it became that their statements were crypto-manifestos for moral constructivism. Both politicians made it clear that shame was something that could be learned and unlearned, that the process of acquiring and relinquishing shame involved political spectacles, and that shame, like language or symbols, was a necessary tool of government.

It is possible that neither the chairman of the victorious political party nor the president of the country realized that they were confirming a thesis proposed by Eve Kosofsky Sedgwick, who observed that "transformational shame is performance."3 According to this concept, both politicians appeared as performers. And while their rigid postures, monotonous gestures, uncoordinated with their words, and dull facial expressions made the performances underwhelming, the verbal layer itself was clear: there is no such thing as inborn shame or the moral autonomy of the individual. Poles had acquired the wrong kind of shame and had developed warped consciences in the years leading up to 2015. Consequently, a change was now in order, and carrying it out called for social conscience engineers, directors of the collective emotion, and affective resource managers.

All of this allows me to formulate my initial theses. I believe, namely, that shaming (or the practical teaching of shame) is a historically variable spectacle entangled in power relations (e.g. parenting, school, work, social groups, politics). The fundamental purpose served by this spectacle is inclusive r ej e c t i o n. Shaming excludes an individual from a given community (family, class at school, social group, nation, religious community) so that the individual will want to belong to it. In order for the excluded to

2 Artur Bartkiewicz, "Prezydent Duda w Gdyni: Wstyd za III RP", rp.pl, December 17, 2015, accessed March 15, 2016, http://www.rp.pl/Historia/151219439-Prezydent-Duda-w-GdyniWstyd-za-III-RP.html\#ap-1/.

3 Eve Kosofsky Sedgwick, "Shame, Theatricality, and Queer Performativity: Henry James's The Art of the Novel," in Touching Feeling: Affect, Pedagogy, Performativity (Durham: Duke University Press, 2003), 38: "I mean theatrical performance. Performance interlines shame as more than just its result or a way of warding it off, though importantly it is those things." 
be reincluded, the individual must achieve a particular d e p e n d e nt a u to n o my, that is, the ability to self-correct their own actions and the actions of others according to the rules of the community. This understanding of shame as bond-forming emotions and tools, ${ }^{4}$ is acquired in social spectacles of ag ency through which we are equipped with moral definitions and reflexes. The dual manner in which shame operates - affecting the body and the consciousness - means that understanding how shame works is not the same as being able to relinquish it. We can blush with shame and be angry at ourselves for blushing. It is possible to know that shame is a cultural practice and still succumb to its impulses. Conversely, we can know the reason for shame and not feel ashamed, contrary to what Socrates believed. Shame only works when it effectively puts on the path of being excluded.

There is no social institution that can survive without shame, and there is no society that could eliminate shame. ${ }^{5}$ Yet the social construction of shame has empirical consequences in the form of multiple and contradictory shaming mechanisms or systems. Individual families, regions, and social groups have different processes of socialization involving the practical teaching of shame (shame is the experience of losing the acceptance of those whom we love, admire, and respect). Such shame - multiplied and operating in the form of contradictory or separate microsystems - would be of little use to the government, which would be unable to co-opt it for the purposes of governing. Yet the statements made by the chairman of the triumphant political party and the president of the country clearly signaled that the government needed shame. Therefore, there must exist some overriding form of shame that integrates all the remaining forms of shame, so that the latter may be employed by the government. This overriding sense of shame may be described as legitimate or sanctioned, the kind that owes its performative efficacy to its belonging to the sanctioned culture. ${ }^{6}$

Such sanctioned shame, which serves as the justification for all ethical judgment, sanctions itself and is thus unquestionable, sharing its power with

4 See for example Joseph Nicolosi, Shame and Attachment Loss: The Practical Work of Reparative Therapy (Downer's Grove, Illinois: IVP Academic, 2009), and Serge Tisseron, La honte: Psychanalyse d'un lien social (Paris: Dunod, 1992).

5 Donald Nathanson, "Shaming Systems in Couples, Families and Institutions," in Many Faces of Shame, ed. Donald Nathanson (New York: Guildford Press, 1987).

6 The sanctioned culture dictates a lifestyle that - while itself immune to questioning (as it generates mechanisms preventing the examination of its foundations) - permits the judging of all lifestyles. I refer to the concept proposed by Pierre Bourdieu: see Pierre Bourdieu, Jean-Claude Passeron, Reproduction in Education, Society and Culture, trans. Richard Nice (London: Sage Publications, 1990). 
no one. It is a moral doxa that binds all social life with a web of convictions. It makes clear what is expected of us and what we have the right to expect of others. Yet shame operates in a mode of asymmetrical symmetry: it allows us to admonish others based on the premise that we, too, are subject to its disciplinary power, but at the same time, the act of shaming someone in compliance with the requirements of sanctioned shame exempts us from having to prove that we ourselves meet the same standards. To put it bluntly: we shame others not just so that they will realign their behavior with the postulated norms, but also to prevent others from shaming us. The act of shaming someone grants our dignity temporary immunity, shielding us from a symmetrical response on the part of the shamed.

On occasion, someone will respond to sanctioned shaming by referring to another sanctioned form of shame, that is, alternative rules that bind the same community together with different values. This is currently taking place in Polish (and central European) culture. ${ }^{7}$ The unprecedented situation we are now witnessing involves the teaching our bodies and consciences a new form of sanctioned shame.

\section{Shame and Modernity}

I do not claim that modernity invented shame, as that would run contrary to evidence reaching back deep into antiquity. Greek and Roman mythology as well as Jewish and Christian ethics had numerous rules that used shame to include the individual in society. Shame - I will leave it at that - appears wherever the collective agrees upon a set of rules to govern its members' coexistence. ${ }^{8}$

I believe, however, that modernity has bestowed a particular role on shame by turning it into a means of progress. It is impossible to call for an overall change of the world without stigmatizing the attitudes that must be eliminated. The social energy needed to achieve a unity of goals requires something

7 In his book The Geopolitics of Emotion: How Cultures of Fear, Humiliation, and Hope are Reshaping the World (New York: Anchor Books, 2010), Dominique Moïsi compiles an affective map of the world. He claims that public moods are representative of cultural tendencies that are typical of specific regions and communities, and that collective emotions influence political conflicts. Based on this assertion, Moïsi divides the world into three areas: Hope (Asia), Humiliation (the Middle East), and Fear (Europe and the United States).

8 See for example Douglas L. Cairns, Aidos. The Psychology and Ethics of Honour and Shame in Ancient Greek Literature (Oxford: Clarendon Press, 1993); Bernard Williams, Shame and Necessity (Berkeley: University of California Press, 1993); Małgorzata Budzowska, "Czy wstyd to «bóg bezczynny»? Ambiwalentny charakter wstydu Fedry," in Spojrzenie Spektakl - Wstyd, ed. Jan Potkański and Robert Pruszczyński (Warszawa: Elipsa, 2011). 
more than just arguments: it requires emotions. That is why liberty, equality, and solidarity have been established, since the beginnings of modernity, with the help of narratives that sway society from ecstasy to shame.

This particular connection between solemnity and shaming can be observed in Immanuel Kant's Answering the Question: What is Enlightenment?, a fundamental text of modernity. Kant's essay expresses a strong connection between the rational praise of reason as the legislator of a total order and the rhetoric of shame that discourages us from using other human capabilities. Read from the rhetorical and affective perspective, the text reveals its true nature as a condescending sermon. In the opening paragraphs, the invectives "laziness and cowardice" play an equally important role as the call to use one's "own understanding":

Enlightenment is man's emergence from his self-imposed nonage. Nonage is the inability to use one's own understanding without another's guidance. This nonage is self-imposed if its causes lie not in lack of understanding but in indecision and lack of courage to use one's own mind without another's guidance. Dare to know! (Sapere aude.) "Have the courage to use your own understanding," is therefore the motto of the enlightenment. Laziness and cowardice are the reasons why such a large part of mankind gladly remain minors all their lives, long after nature has freed them from external guidance. They are the reasons why it is so easy for others to set themselves up as guardians. It is so comfortable to be a minor. If I have a book that thinks for me, a pastor who acts as my conscience, a physician who prescribes my diet, and so on - then I have no need to exert myself. I have no need to think, if only I can pay; others will take care of that disagreeable business for me. Those guardians who have kindly taken supervision upon themselves see to it that the overwhelming majority of mankind - among them the entire fair sex - should consider the step to maturity, not only as hard, but as extremely dangerous. ${ }^{9}$

Kant thus urged us to use our own reason boldly, warning us against mental dependence. A person who allows a wise man to think for him, a priest to resolve his moral dilemmas, and a doctor to manage his body does not simply "lack understanding," but is actually a slave to his own caretakers. In order to begin defining the order of the individual and collective world on the grounds of reason, it was first necessary to feel shame for one's dependence, cowardice, and laziness.

9 Immanuel Kant, "What is Enlightenment?," trans. Peter Gay, in Introduction to Contemporary Civilization in the West (New York: Columbia University Press, 1954) 2:1071-1072. 
Three decades earlier, Jean-Jacques Rousseau, debating the Polish King Jan Leszczyński on the subject of equality, wrote that "the first source of evil is inequality."10 Later, in his Discourse on Inequality, he described property as the source of all inequality, contrasting it with the virtue of pity: "[...] for all their morality, men would never have been anything but monsters if Nature had not given them pity in support of reason [...];" "While Socrates and minds of his stamp may be able to acquire virtue through reason, mankind would long ago have ceased to be if its preservation had depended solely on the reasonings of those who make it up."11 The concept of pity as an inborn virtue and moral order as a derivative of that virtue activates the story of another kind of shame. While Kantian rhetoric stigmatized submission to authorities, saying "Shame on you for being dependent," Rousseau adjudicated: "Shame on you for being indifferent." In his letter to the king, the Discourse on Inequality (1755), and The Social Contract (1762), he argues for the establishment of an order founded on compassionate socialization. The readers of Rousseau's letter (and his other writings) could no longer hold that all inequality was natural and/or beneficial, just as they could no longer hold that the identification of inequality through reason was a fulfillment of man's duty. Reason was not everything: the call for rational understanding was to be reinforced with compassion, active cooperation on a new social contract, and the abolishment of conditions that dampened the natural virtue of pity.

There are other legislators of modernity who could appear alongside Kant and Rousseau. ${ }^{\mathbf{1 2}}$ What they have in common is that instead of resorting to judgment and punishment as consequences for violating the social order, they use the shield of shame to protect the values they have introduced. Let him be ashamed who cannot gather the courage to use reason, who is incapable of pitying his neighbor, who lacks goodwill towards others... The history of modernity can be told as the story of shame, because modernity owes its dynamic to various concepts of shame and the different methods in which

10 Jean-Jacques Rousseau, "Observations by Jean-Jacques Rousseau of Geneva on the Reply Made to his Discourse," trans. Judith Bush, in On Philosophy, Morality, and Religion, ed. Christopher Kelly (Hanover, New Hampshire: Dartmouth College Press, 2007), 12.

Rousseau, "A Discourse on the Origin and the Foundation of Inequality Among Men," in The Discourses and Other Early Political Writings, ed. and trans. Victor Gourevitch (Cambridge: Cambridge University Press, 1997), 1:153-154.

These include Edmund Burke, who, in his Reflections on the Revolution in France (1790), wrote that social and political order are guaranteed by the habits and sympathies of the people; and Joseph de Maistre, who advocated absolutism, arguing that it was the only system that could achieve maximum social respect, thus guaranteeing order, and added that the ruler was as obligated to respect the law as were his subjects. 
this shame was instituted. Two different and potentially conflicting forms of shame are most prominent in this regard: the first falls upon modern people who are insufficiently independent in their use of reason, while the second falls upon those who are insufficiently socialized and engaged in the liberation of their neighbors from the shackles of inequality. The former shaming contributes to the rational ordering of the world, while the latter contributes to a world bound by solidarity. The likelihood that the two might come into conflict results from the fact that society can only be convinced to accept the autonomy of reason when we shame the inclinations of the heart. Meanwhile, society can only be convinced to assume a stance of solidarity when we shame the human predisposition for excluding morality and empathy from legislation. Proponents of either concept must appeal to disparate emotions in order to make the future world a better place. Yet there is no certainty that they have the same world in mind. The contradiction between the shame of cowardly irrationality and that of antisocial indifference is not inevitable, however. It can be avoided by a society that foresees the impending clash and establishes an order that combines the search for truth with the pursuit of solidarity.

Jürgen Habermas made the same observation when, with his usual perspicacity, he referred to Kant in the famous speech titled Modernity: An Unfinished Project (1980):

With the definitive segregation of science, morality and art into autonomous spheres split off from the lifeworld and administered by specialists, all that remains of cultural modernity is what is left after renouncing the project of modernity itself. The resulting space is to be filled by traditions which are to be spared all demands for justification $[\ldots]{ }^{.13}$

Habermas called for loyalty to a legitimation that would establish the lost connection between pure reason, practical reason, and the power of judgment. The rhetoric of shame is less pronounced here, but it returns in a milder form when the author reiterates Kant's admonition against mindless acquiescence to "tradition," which is absolved by the power of its eternal nature from the need to justify its foundations and substantiate its claims.

Let me repeat: modernity did not invent shame. What it did was give it a radical form that extracted from it the energy needed to abandon our former rules of life and embark on the creation of a new order. Modernity entangled

13 Jürgen Habermas, "Modernity: An Unfinished Project," trans. Nicholas Walker, in Habermas And the Unfinished Project of Modernity. Critical Essays on The Philosophical Discourse of Modernity, ed. Maurizio Passerin d'Entreves and Seyla Benhabib (Cambridge, Massachusetts: MIT Press, 1997), 54. 
shame into the mechanisms of power and the practices of creating a total social order. In establishing a new anthropology of shame, modernity promised the ecstasy of liberation through reason and social integration. When that source of collective ecstasy ran dry, modernity entered into a period of decline. Postmodernism turned out to be Modernism without solidarity or equality.

It is possible to determine the approximate moment in which collective ecstasy - the reward for avoiding peculiarly modern forms of shame - disappeared from the narratives that design society. It was the mid 1980s. In 1986, Jean-François Lyotard published the essay Answering the Question: What is Postmodernism?:

The nineteenth and twentieth centuries have given us as much terror as we can take. We have paid a high enough price for the nostalgia of the whole and the one, for the reconciliation of the concept and the sensible, of the transparent and the communicable experience. Under the general demand for slackening and for appeasement, we can hear the mutterings of the desire for a return of terror, for the realization of the fantasy to seize reality. The answer is: Let us wage a war on totality; let us be witnesses to the unpresentable; let us activate the differences and save the honor of the name. ${ }^{14}$

Lyotard's aesthetic concept was a reference to Kant and a direct response to Habermas. He perceived in the pursuit of unity the threat of the nationalization and socialization of violence. Lyotard's essay concludes the reflections initiated by Adorno and Horkheimer's Dialectic of Enlightenment, which posited that Enlightenment universalism inevitably led to the creation of the death camps. In this modified historical and political context, the definition of postmodernism blazed a new trail, one that led from shame over insufficient social integration to shame over excessive interference into the lives of others. The French philosopher's pathos stood guard over the fundamental commandment of the new era: Thou shalt leave the Other alone.

\section{Founding Shame}

The idea of difference breathed life into Polish culture in the mid 1980s. Literature pursued this idea by borrowing from various sources and making references to different historical eras, thus inventing a new society, one that

14 Jean-François Lyotard, "Answering the Question: What is Postmodernism?," trans. Régis Durand, in Philosophers on ArtFrom Kant to the Postmodernists: A Critical Reader, ed. Christopher Want (New York: Columbia University Press, 2010), 248-249. 
was internally diverse and cognizant of the complexity of those differences, and whose memory reached back to the Second Polish Republic; a society that wistfully pondered the loss of that multitude, painstakingly recreating the traces of annihilated communities and remorsefully identifying the layers of the post-war world under which those traces were hidden.

The most important books of that period - admittedly an extraordinarily rich one, full of concealed tensions and ideas for their resolution - depicted a world that was inhabited by spirits and specters of the past: Sublokatorka [The Subtenant] by Hanna Krall, Poczatek [The Beautiful Mrs. Seidenman] by Andrzej Szczypiorski, Bohin by Taduesz Konwicki, Stan po zapaści [After the Collapse] by Jacek Bocheński, Weiser [Who Was David Weiser] by Paweł Huelle, Zagłada [Annihilation] by Piotr Szewc, Umschlagplatz [The Final Station. Umschlagplatz] by Jarosław Marek Rymkiewicz, Cesarski walc [The Imperial Waltz], Ocaleni [The Survivors] and Strażnik świąt [The Guardian of the Holy Days] by Stanisław Benski, Kadysz [California Kaddish] by Henryk Grynberg, Skrawek czasu [A Scrap of Time] by Ida Fink, and Teatr zawsze grany [The Theater That is Always Playing] by Adolf Rudnicki are just a modest selection of books published in the years 1985-1988. Add to that Echo [Echo] by Julian Stryjkowski, a sequel to Gtosy w ciemności [Voices in the Darkness], and the same author's debut book titled Milczenie [Silence], and we begin to understand the particular reconfiguration affecting cultural shame during the late 1980 s and early 1990 s. Cultural shame was retroactively cast upon those who once acted with indifference to the tragedy experienced by the Jews, Lemkos, and Kashubians. It was cast upon those who forced sexual minorities to live a life of silence and upon those who excised women from the pages of shared history. It tainted contemporary Poles with shame over their stalled emancipation. Many narratives paint an image of Polish modernity as the incomplete process of empowering Others, a process that demands to be finalized.

The great debt owed to the Other, a debt that continued to mount due to forced assimilation and acts of discrimination, demanded immediate repayment. The problem was that the guilt for that incomplete emancipation lay primarily on the old ideas of social unity, which inevitably led to violence against minorities. The reckoning over those ideas - a reckoning rooted in emancipatory traditions - contributed to the deconstruction of normative unities. The consequence of this lack of narrative about some shared history, shared social goals, or at least shared goals other than that of protecting individuality from shared goals, was precisely the one Habermas feared: the segregation of science, morality, and art. A lone subject remained on the stage of history, one free and ready to enter the deconstructive games played with collective identities and perceiving his individuality as a source 
of melancholic ecstasy. A new form of shame known as intolerance stood guard over his freedom. The term would be used against anyone who attempted in the 1990s to impose on the Other a homogeneous - particularly national or Catholic - lifestyle or form of identity, anyone who would reject the Other's right to otherness, anyone who would demand that the Other once again feel ashamed for transgressing the general norm.

The problem was that this newly emancipated subject would have to consider a new shame that would inevitably befall him: the shame of dependence. This was not dependence in the Kantian sense, the kind that resulted from mental laziness, but rather its derivative, a dependence adapted to the conditions in the fledgling capitalist state. It was a lack of independence in life (financial, personal, professional) that would now encumber the individual person. Now that he had been given his freedom, he would have to take full responsibility for his life. Any joy in his family life, professional success, and minor and greater public triumphs would all be added to his account. Yet the same was true of emotional failures, professional missteps, and public humiliations. His previous shame over his insufficient solidarity with his neighbor turned into shame over insufficient tolerance, which in turn became a negative form of freedom from his neighbor.

The area in which this conversion could occur was the history of collective life. This is where the critical stories of intolerance against minorities met with the neoliberal narrative about the necessity of individualizing one's participation in history. In order for this conversion to occur, it was necessary to imagine collective history as a reservoir from which one must draw maximum shame and minimum pride. According to this logic, the memory of past crimes, which were driven by collective xenophobia and intolerance, began to be used to shame contemporary collective subjects. Instances of the heroic defense of Others become the sole justified source of pride. The tragic histories of minorities - represented by Eliasz Szyra (Konwicki's Bohin'), David Weiser (Huelle), Irma Seidenman (Szczypiorski's The Beautiful Mrs. Seidenman), the Jews of Zamość in the novel by Piotr Szewc, the Gypsies recalled by Jerzy Ficowski, the Masurians depicted in Erwin Kruk's Kronika z Mazur [A Masurian Chronicle] - were to give rise to a society pluralistically bound by the principle of concern for their neighbors. In the 1990s this society was harnessed into a narrative that presented violence against the Other as something that was avoidable only by limiting assistance to the Other.

\section{More than just Shame}

The emancipation of the discriminated Others was made possible by according them equal rights, thus relieving the assimilatory pressure exerted by the 
collective identity. That same relaxation of social bonds facilitated the systemic transformation of the country and the neoliberal deregulation of collective subjects such as social classes, religious communities, and the nation. The neoliberal discourse gradually monopolized the concept of freedom, absolving the state of its responsibility to ensure equality.

Under these circumstances, the position of people who happened to win approval precisely from their standing in their families, social classes, or national or religious communities became precarious. They were soon stripped of any vestiges of symbolic prestige. Those who required help rather than emancipation found themselves in a similar predicament. Not only were they forced to reach out for that help, they also had to swallow an ever growing dose of shame.

The art of the opening decade of the twenty-first century - by which I mean drama, prose, film, and the visual arts - was focused precisely on identifying the changing rules that governed social life, that is, desolidarization, the gradual disappearance of equality from the field of vision, the accumulation of old and new rules of discrimination, and the acquisition of new freedoms and the loss of others. The deconstruction of the politics of affect, particularly the new distribution of shame and approval, began to play a crucial role in the critical action of art.

Among these deconstructive operations, there are three fundamental ones that can be discerned.These involved, in succession, the depiction of the process of implementing shame, its consequences, and how it could be prevented.

Scene one involved a new pedagogy of shame, coordinated by no one and carried out chiefly in the areas of economic and cultural advancement, where it demanded an increasing degree of submission. A model example of this can be found in the plays of Paweł Demirski. In his later work - which includes the plays From Poland With Love (2006), Kiedy przyjda podpalic dom, to sięnie zdziw [Don't Be Surprised When They Come to Burn Your House Down, 2006], Śmierć podatnika [Death of a Taxpayer, 2007], Diamenty to wegiel, który wzią się do roboty [Diamonds are Coal That Got Down To Business, 2008], Opera gospodarcza dla ładnych pań i zamożnych panów [An Economic Opera for Nice Ladies and Wealthy Lords, 2008], and Wimie Jakuba S. [In the Name of Jakub S., 2011] - we witness the playwright's transformation from a critic of capitalism who exposes the hidden mechanism of the market, to a critic of the liberal discourse, that is, an artist who deconstructs the validity of the new rules.

In the early play Don't Be Surprised..., Demirski echoes the work of leftleaning pre-World War II artists by presenting the ruthless battle waged by capital against the worker; beginning with Death of a Taxpayer, he shows how neoliberalism wins the battle using ideology rather than by the power of sheer money. Thus the author creates characters who not only suffer defeat 
in their confrontation with this new world, but who must also articulate their defeat in a new language. They are to be humiliated, not just defeated. They are forced to admit that their downfall was well deserved, that they turned out to be weaker in a fair fight. The language of neoliberalism thus equates the defeated and the excluded, leaving one and the other to fend for themselves. In Diamonds... Sonia recites the following lesson about Uncle: "His archaic habits of all-too-obvious origin... hindered him from understanding what was good for him. As a result, he lost out, and there's nothing better in store for him anymore."15

Demirski additionally writes into his plays officials of the new discourse, that is, people whose job it is to teach these lessons in humiliation to the defeated characters. Thus Sonia directs this straightforward explanation to Uncle: "Exactly - this play is about a hundred-year-old, Uncle - for a hundred years now, there've been uncles like you, and there's nothing anyone can do about it - just like there's nothing anyone can do about poverty and social exclusion, which is the cost you have to pay for transformation and our neoliberal economy; and your character, Uncle, has precisely this educational tenor."16 It is apparent that Sonia's cynicism affects Wojnicki, but it also educates the audience; we begin to understand that success narratives and the vocabulary of systemic transformation have become agents of economic processes and accomplices in the overhaul of our way of thinking. The transformation of affects strengthened the economy, turning peoples' various, ordinary market missteps into a sense of shame for their lack of self-sufficiency.

Yet neoliberalism constructed a new sense of shame not when it created the poor, but when it popularized the notion that the losers were themselves at fault. In the final monologue, addressed not so much to the characters as much as it is to the audience, Wojnicki remarks: "The worst thing about this story is that / I'm no good. / That I was told that I was no good. / And I know that I'm no good. / That I'm not up to dealing with all of this somehow. / That I couldn't find myself. / And I know that, but it doesn't change a thing for me, / knowing / that there are people who are up to it."17 Discourse locks the losers up in a world of necessity, but it does not throw away the key; like any other shame, the one that affects the losers simultaneously excludes and includes

15 Paweł Demirski, "Diamonds are Coal that Got Down to Business," in (A)pollonia: Twentyfirst Century Polish Drama and Texts for the Stage, ed. Krystyna Duniec et al. (London: Seagull Books, 2014), 476. 
them, giving everyone the opportunity to return to the sphere of approval under the condition that they accept their circumstances as shameful. ${ }^{18}$

How did the ethics of the Other - espoused in the past - come to be conflated with the newer pragmatics of individualism? Dziady. Ekshumacja (Forefathers'Eve. Exhumation) and An Economic Opera...- a paraphrase of Brecht's The Threepenny Opera, itself a paraphrase of John Gay's The Beggar's Opera - is an abridged staging of the birth of the Polish free market which explains the downfall of solidarity and the rise of the new shame. In Demirski's depiction, each stage of Poland's struggle for independence - from the period of partitions to 1989 - was sold out by the victors in the process of transformation. As we watch the characters on stage, we find ourselves at a loss for counter-arguments. The division into winners and losers proves that while the twenty-year battle might have been fought over freedom, it was the free market that won in the end. If so, then those who helped build capitalism in its infancy are the most deserving of approval, while those who are able to convert their merits of yesterday into the privileges of today are the most deserving of freedom. Consequently, Mickiewicz's Konrad combines with Brecht's Mack the Knife, while Andrzej Wajda, portrayed in the drama Byt sobie Andrzej, Andrzej, Andrzej, and Andrzej], [There Was Andrzej, Andrzej, Andrzej and Andrzej], merges with Jan Kulczyk.

Peachum, the main character of An Economic Opera..., appears to be a bastardly synthesis of such different fathers. In the time of the Polish People's Republic he was "persecuted" by the state for being a private entrepreneur. Now, as a veteran, he transforms his dubious involvement in the anti-communist resistance into profit. He is a member of the elite Association of Former Prisoners for Prosperity, which works to strengthen the ties between economic and political power. His organization is a Polish transplant of the WASP agenda in mafia form: "The people in our association are normal / rich / white / conservatively liberal."19 Together, they form the most hermetic club of managers in the country, one that professes an astonishingly straightforward ideology: freedom is the liberty to accumulate capital. Get rich if you can, and if you can't, then you can just fuck off. ${ }^{20}$

The unification of cultural capital with capitalism and freedom with the free market meant that the national uprisings of the nineteenth century, the

18 See Sedgwick, "Shame, Theatricality, and Queer Performativity," 37: "[...] Shame both derives from and aims toward sociability."

19 Demirski, „Opera gospodarcza dla ładnych pań i zamożnych panów," in Parafrazy (Warszawa: Wydawnictwo Krytyki Politycznej, 2011), 285.

20 See the song "Spierdalaj" for two sopranos, violin, bass guitar, and drums: Demirski, Opera, 296. 
resistance, Siberian exile, and finally the social upheavals witnessed in the Polish People's Republic were nothing more than the struggle for the right to get rich, to be selfish, and to transform the state into a service sector. "It's my way or the highway," Peachum says. Still, the class he belongs to does not want to appear selfish. The Peachums of our times still experience a modicum of shame over their lack of solidarity, yet the shame caused by dependence legitimizes greediness, and thus they take economic considerations into account in their generosity towards the poor. They turn solidarity into philanthropy, they convert philanthropy into prestige, and prestige in turn ushers them into the cultural elite, making them socially trusted figures to whom serious contracts can be awarded. This whole series concludes with a trap that ensnares the "shamed losers" - not only does the act of sanctioned philanthropy curtail the duties of the state in combating inequality, it furthermore turns inequality into a problem to be resolved not through legislative means, but in the realm of private charity. Thus the shame over the lack of solidarity, which Rousseau would have placed at the foundations upon which the order of the republic is to be built, winds up outside the social contract as an optional factor. It places shame exclusively upon the shoulders of the "losers."

In depicting these exercises in shaming, Demirski naturally casts a spotlight on those who participated in such exercises, that is, members of the elite. In this regard, Demirski's plays became a continuation of the type of prose prevalent in the 1990s, in which a single character was quickly identified and molested by symbolic means. He was the first winner of the freemarket race: the petty hustler, the smalltime Polish capitalist who hastily and sloppily covered up his plebeian background as he assumed a business class guise. His garb, appearance, behavior, manners, and taste became culturally stigmatized, while he himself earned the dubious name of homo polonicus. He crops up in the writing of many authors: Marek Nowakowski (Homo polonicus, 1992; Skandal w motelu „George” [Scandal at Motel George], 1997; Prawo prerii [The Law of the Prairie], 1999), Tadeusz Konwicki (Czytadto [Airport Novel], 1992), Piotr Wojciechowski (Szkoła wdzięku i przetrwania [The School of Charm and Survival], 1995), Krzysztof Maria Załuski (Hotel Polonia, 1999), Włodzimierz Kowalewski (the short story Rude włosy noca [Red Hair in the Night], published in Powrót do Breitenheide [Return to Breitenheide], 1997). In later years, this petty hustler would either lose, or - in the case of Demirski's plays - accumulate economic capital and amass political influence. The difference between the prose writers and Demirski is that while the former attempted to shame the nouveau riche and guide them onto the path of righteousness, the playwright gave the members of the elite the opportunity to explain how they exploit shame to maintain their positions. Ushered 
onto the stage, the beneficiaries of the systemic transformation assert with disarming cynicism that they owe their success to no one but themselves, and that everyone else ought to exercise self-sufficiency as well. Thus, sanctioned shame began to protect the victors.

Demirski's plays depict the assorted practices through which shame is implemented, often through the use of scenes that are rife with humiliation. If that was the first scene, then the next one played out in the dramas by Dorota Masłowska, who brought out characters that had already been trained to react differently. The shift in perspective seems crucial in this regard: in the novels Wojna polsko-ruska pod flaga biało-czerwona [Snow White and Russian Red] and Paw królowej [The Queen's Peacock], the author exposes to public view and humiliates pathetic Polish manifestations of misogyny. The books cast a pall of shame over the local figure of the Polish macho who expects approval for simply being a Pole, a man, and a sexist. Meanwhile, the plays Dwoje biednych $R u$ munów mówiacych po polsku [A Couple of Poor, Polish-Speaking Romanians, 2006] and Między nami dobrze jest [No Matter How Hard We Tried, 2008] feature female characters who behave as if they had been too diligent in their lessons and had internalized the social engineering technique that is loser's guilt.

The immune systems shielding their morals and personalities gradually break down under the pressure of liberal and free-market pedagogy. If they choose not to heed these lesson, then they must pretend to be someone they are not. After all, if Poland is in fact "worse than Romania,"21 then another identity has to be forged: "I've long since made up my mind that I'm not Polish, just European, and I learned the language from records and tapes left behind by the Polish cleaning lady. We're no Poles, we're just Europeans, normal people." 22 If, on the other hand, they decide that they are who they are and that "we're all good," then they have to assemble a language that would justify their present circumstances. This language would have to express an idea that stands in contradiction to what is eye-witnessed: that the excluded could be even more excluded; and if they're not, then that means they still stand a chance of succeeding in the market:

Halina: "The primroses are in flower, and spring is well upon us [...]. You're more inclined not to go on invigorating walks; it's time not to break out that bicycle you don't own. [...] It's not back on the hanger with those grays, browns, bulky tights, thick sweaters, coats and jackets. Dare not to

21 Dorota Masłowska, "Dwoje biednych Rumunów mówiących po polsku," in Dwa dramaty zebrane (Warszawa: Lampa i Iskra Boża, 2010), 40. 
wear those breezy dresses you don't own and the fine tights you don't own either. Most likely you don't have any lighter jackets, but the one you do have certainly won't fit your fat frame. Not to worry. We have last year's tips to keep you from landing squarely on the sidelines with your finger on the sphincter of springtime trends."23

The multiple negations drive the language into a state of functional contradiction: it at once conceals and reveals, at once mystifies and discredits. It allows the lack of options to be presented as a series of negative choices ("I keep thinking about the holiday I won't be having. I've been reading up on it, and I've finally decided: No way, we're not going on holiday again this year."24), while discrediting helpless efforts to conceal this lack of options; it reveals the misery of her hopes and denounces the source of that misery.

Masłowska thus catches shame red-handed as it attempts to mask itself. Shame is the master of disguise ${ }^{25}$ and is not easy to expose. The writer reveals how shame hides beneath rationalized and naturalized human behaviors as a regulating principle. It determines one's self esteem and readiness to stand up for oneself. People who know that they might be shamed will withdraw from the world and choose a place that will limit their exposure to unpleasant experiences, even though that withdrawal hinders the very actions that could help them unshackle themselves from shame. In other words, shame is the cause of actions undertaken in order to prevent action.

\section{Not Quite Resistance}

In the same decade in which Demirski and Masłowska deconstructed shaming methods and their social consequences, there appeared works of literature that explored characteristic self-defense tactics. The first, as ineffective as it was obvious, involved submitting to shame in public and revealing one's own emotions in private. Yet in this case the family or social circles are not used by the characters as laboratories in which to exercise their powers of resistance or develop alternate stances. Rather, they are spaces for emotional release. The characters thus live in two alternating worlds of suffered humiliation and helplessly shouted profanities.

Like the masses of millions in whose name they had been summoned into literature, they suffered the experience of unemployment and humiliating

\footnotetext{
23 Ibid., 428.

24 Ibid., 433.

25 See Jane Middelton-Moz, Shame and Guilt: Masters of Disguise (London: $\mathrm{HCl}, 1991$ ).
} 
job interviews. While Demirski lent a voice to the elite and allowed them to speak in the language of shame, full of condescension, contempt, and cynicism, these authors equipped their characters with the awareness of the goal that this shame was intended to achieve. They know which slogans to use to land a job, and they know that the use of these slogans is a sign of submission that is expected by the employer. Hence their language is grotesquely servile and repulsively honest:26

[...] I hereby consent to the processing of my personal data and internal organs for the purposes of food preparation and packaging. I consent to extensive penetration and interference. ${ }^{27}$

Please find attached the intriguing résumé of a graduate with a degree in an interesting yet dead-end major. I have a hundred years' experience in everything, I've given more hummers to CEOs than General Motors, and I can operate any device, from iPhones to photocopiers to lawnmowers. I'm fluent in ten languages, with a particular emphasis on hate speech. ${ }^{28}$

This incohesive yet essential combination of significant competence (ten languages) with pent-up negative emotions (hatred) signaled the alarming increase in the disproportion between sources of approval and sources of defeat. A growing number of experiences, types of biographies, behaviors, and aesthetics were becoming shameful in nature: a small-town or rural background (M. Olszewski, M. Pilot, M. Szarejko), a mediocre fortune amassed under communism thanks to connections and fraud (M. Nowakowski), big money earned under communism thanks to membership in the state apparatus (G. Mérétik, Kryptonim Luksemburg [Code-Name Luxembourg]), and minor and major fortunes acquired under capitalism (Nowakowski, Wojciechowski, Łoziński). From this jumble of characters and their actions emerged an increasingly expansive network that began to encompass all of reality. ${ }^{29}$

26 In the version that more closely resembles reportage, the language is stripped of this directly-expressed awareness of one's own humiliation. See for example: "Czarek was going on forty. His baseball cap read: How may I help you?" - Marcin Kołodziejczyk, B. Opowieści z planety prowincja (Warszawa: Wielka Litera, 2013), 92.

27 Sławomir Shuty, Zwał (Warszawa: WAB, 2004), 100.

28 Patrycja Pustkowiak, Nocne zwierzęta (Warszawa: WAB, 2013), 86-87.

29 Marek Ziółkowski, "O imitacyjnej modernizacji społeczeństwa polskiego," in Imponderabilia wielkiej zmiany. Mentalność, wartości i więzi społeczne czasów transformacji, ed. Piotr 
What was of course unprecedented was the systemic transformation itself, that is, the shift from a centrally-planned economy to a free-market one, from an anti-communist identity that concealed diversity in society to multiple identities whose foundations had not yet fully formed, and from ritualized elections to a democratic election process. Under such circumstances - perhaps understandably and less reprehensibly - everyone attempted to shame everyone else, for various reasons and from various positions: the poor shamed the rich, the elite shamed the commoners, those who demonstrated solidarity shamed those who were selfish, the nationalists shamed the post-communists, and the post-communists shamed the liberals. This was brought about by the gradual crystallization of sanctioned shame. Yet the results were grotesque. By the time the country was done carpet-bombing itself with shame, the only Pole who could avoid shame turned out to be one deeply-rooted in the local tradition, namely, the ghost-Pole: a phantom who marched into this new reality with no connections, money, or education, who came from nowhere, and who relied on his street smarts rather than market skills to earn a living.

Piotr Siemion's novel Niskie Łąki [Low Meadows, 200o], provided a perfect illustration of this apparition. It told the story of a group of young people who formed the avant-garde of the Orange Alternative: unemployed and unenrolled in university, they make a living by committing minor acts of theft, but only when necessary; they paint slogans on walls during martial law, but they never formally join the underground Solidarity movement; they move to the United States in the final years of the Polish People's Republic, but return with no cash at the turn of the decade. They set up a radio station, even though they have no money, insufficient professional experience, and no connections. Siemion thus depicts an idealized version of the birth of the middle class, a class of self-made men who do not owe anything to anyone. Tasked with overseeing the station's social mission, they remain pure not just in the professional sense, but especially in terms of their biographies: their life stories in the years leading up to the Third Polish Republic are one long improvisation during which they put down no permanent roots. With no connections or origin, no money or skills, demonstrating solidarity in a free-market world, socially

Sztompka (Warszawa: Wydawnictwo Naukowe PWN, 1999), 55-56."The reality (or, rather, hyperreality) depicted in Western, mainly American, films and cartoons is - particularly for the younger generation - becoming a point of comparative reference, or even increasingly a point of normative reference against which to judge everyday life in Poland. Krzysztofek [...] goes as far as to refer to signs of the «cultural shaming of Poles», expressed in their contempt for their native culture and language, and their fascination with the mass-produced culture that flows in from foreign, mainly American, media outlets." 
conscious in his commercial ventures: these are the qualities of the phantom Pole who might avoid being shamed in this new world.

It was a logical response to the spread and instrumentalization of shame. Its spread proved, after all, that systemic transformation was dependent on a mental and affective transformation. The aforementioned shame that was cast upon crude flea-market capitalism was intended as an encouragement to imitate Western-style capitalism. Complementary to it was the concurrent sense of shame over the Polish People's Republic. ${ }^{30}$ Its disciplining metaphor was proposed by Józef Tischner in the seminal essay Homo sovieticus (1991), in which he defined Homo sovieticus as "a client of communism, enslaved by the system"; the "client" was responsible for the collapse of the former system, but now "demands that capitalists satisfy those needs that the communists failed to satisfy. He is like a slave who, having liberated himself from one form of bondage, immediately sets out in search of a new one." ${ }^{31}$ In keeping with his own Hegelian outlook, Tischner denounced the slave mindset that emerged in circumstances that (allegedly) enabled anyone to become his own master. His conclusion sounded cruel, but not inconsistent in this regard: "[...] let me be clear: even those who experience great suffering are not permitted to do whatever they please. Those who suffer also bear responsibility for their actions and are subject to criticism. We cannot, after all, treat them as children. While this may strike some as degrading the dignity of sufferers, it is in fact the restitution of their dignity." ${ }^{32}$ This line of reasoning justified the withholding of respect for adults orphaned by the communist system, adults who were now expected to acknowledge their own responsibility for their present circumstances. Ewa Borzęcka upholds this disciplinary perspective in her painfully colonialist documentary Arizona (1997), which depicts life in a village where the state agricultural farm has been shut down and the local peasants, abandoned by their master, can do nothing but drink themselves blind.

Thus the self-taught capitalist was shamed into broadening and modernizing the flow of capital, while the post-communist client, with his demands against his new masters, was encouraged to become more enterprising and economically independent. Both became synonymous with the "typical Pole," a figure that manifested as an intolerant person who thought about society in terms of unity rather than diversity, an obstinate and narrow-minded

30 See Wstyd za PRL i nie tylko, ed. Katarzyna Łozowska (Szczecin: Przedsiębiorstwo Produkcyjno-Handlowe Zapol Dmochowski-Sobczyk, 2010). 
conservative who regarded pluralism as the cause of various misfortunes. He carried within him frustration rather than views and rational arguments. His Catholicism was small-minded, his patriotism filled with hatred to bogus foreigners, and his own horizons were circumscribed by his convictions on the biological nature of gender, ethnicity, and sexuality. He considered all forms of otherness immoral and unnatural. The shaming of his backwardness, the mental backwater he inhabited, and the parochial Polishness he represented served to broaden and Europeanize the Polish identity.

It was precisely this creation of "shameful" characters by literature and the media that threatened to shame everything considered "normal" in post-transformational Poland. This shaming resulted in the social marginalization of a broad range of experiences together with the ways of life from which they stemmed: the period of the Polish People's Republic, the dawn of capitalism, and the traditionalist collective identity. If they could be kept silent, it would mean that the society involved in the reality of capitalism lacked any characteristic aesthetic through which to depict homespun capitalism, that the collective biography steeped in the Polish People's Republic could not be voided, under penalty of loss of approval, and that there existed no reputable means of communication through which traditional mores could be expressed.

It was a matter of historical and cultural coincidence (and non-coincidence) that two novels were published the same year (2007): the first, $\mathrm{Na}$ grobek z lastryko [Terrazzo Gravestone] by Krzysztof Varga, depicts a character who has absorbed not only the full range of post-transformational shames, but also the colonial principle "minimum shame, maximum pride," meaning that one cannot draw upon any positive content in the history of one's own community; Poland's history as a source of suffering drives the main character of Nagrobek z lastryko into deep frustration (and, in turn, to murder and suicide). The other novel was Barbara Radziwitłówna zaworzna-Szczakowej [Barbara Radziwiłłówna of Jaworzno-Szczakowa, 2007] by Michał Witkowski. Emblematic to the point of relevance, the book introduces a character who carries within him - and on him - all of the founding shames of the new Poland: he succeeded in earning a meager fortune through various shady dealings in the twilight years of the Polish People's Republic; in the Third Polish Republic, he owns a pawn shop (where the poor hock their family treasures), lends money, and works in debt collection; his lifestyle (the gym, a pair of Ukrainian bodyguards on either side, bodybuilding supplements) is the epitome of macho tackiness, while his moral code (violence on weekdays, church on holidays) sets the average for hypocrisy in society.

Witkowski uses all of this to achieve something crucial: he transforms post-transformational shames into tackiness. He replaces behaviors that were 
submitted to moral judgment with choices that were subject to aesthetic criticism, while ennobling the attitudes and objects that had been shifted into the realm of tackiness.

It is precisely for these reasons that the novel can be regarded as emblematic. The author placed in stark relief the process that was under way throughout the country's social life, and three important questions regarding people's collective experiences (What do we owe to the People's Republic of Poland? How did we create capitalism? What system of morality do we represent?) were at risk of being denigrated to a secret, lower, more shameful level of expression. Witkowski preserved and enhanced this worseness (i.e. tackiness) of the post-communist society's roots in the former system, the pawn shop origins of Polish capitalism, and the people's xenophobic mentality, reinforced by its colonial longings. By exhibiting and theatricalizing worseness, Witkowski proved that the plebeian lifestyle was an offshoot of a system of communication that encompassed myriad forms of approval which members of society granted each other. In other words, Barbara Radziwiłtówna... demonstrated the self-sufficiency of the way of life that was put to shame in the transformation process. If sanctioned culture shamed Poles into renouncing the Polish People's Republic, into becoming more independent, more European, and religiously tolerant, then Witkowski's novel proved that the modernization process had run its course. Barbara Radziwittowna... signaled the depletion of the energy that was being drawn from shame to fuel the transformation.

Thus we hit the wall of modernization. The shame that was intended to help create a more pluralistic and solidary society instead sanctioned the policy of granting freedom to those who could take advantage of it; the shame that was intended to encourage modern mobility instead pushed a significant portion of society into opting for defensive immobilization; the shame cast upon traditional mores in hopes of provoking Europeanization instead evoked a sense of worseness, which the majority turned into frustration and some translated into aggression. If I previously defined shame as inclusive rejection, then there was no cohesive "us" to which one could belong in the first decade of the twenty-first century. Sanctioned shame was crumbling into conflicted strands - emancipatory, liberal, conservative - exposing the vestigial nature of the sanctioned culture in which it was purportedly rooted.

\section{Inclusion}

The affective history of Polish culture over the past quarter century outlined in this essay allows us to understand the "community turn" witnessed 
in Polish art in the first decade of the twenty-first century. It was not - or at least not initially - part of an attempt to introduce yet another system of shame, this time one embedded in nationalism. Rather, it seems to me that it was an effort to reinstate the prosocial properties of shame. The goal was to reclaim its inclusive power. This, however, required a shift towards the independent distribution of approval.

Shame over the lack of solidarity was also intended to have a prosocial effect at the dawn of modernity. It was converted in the period of systemic transformation, however, into shame over belonging to collective entities: those who made demands were shamed for their dependence on others, while those who were xenophobic were shamed for their irrationality. It was for this reason that shaming spectacles had an individualizing effect.

The opposite was true in the case of the art associated with the community turn. It comprises works belonging to various disciplines, and so while I will discuss only a handful of plays and novels, I am aware of the existence of many others. ${ }^{33}$ The first example that ought to be mentioned is that of the television drama, as this medium was the first to implement a radical change in the poetics of representation. While produced with the intellectual in mind, it served to foster a classless audience, and was comparable to British theater in terms of its accomplishments and breadth. The plays presented in this format featured new thematic choices and axiological solutions. The titles included: Śmierć rotmistrza Pileckiego [The Death of Captain Pilecki, 2006] about a Polish resistance fighter in World War II who was arrested, tortured, and murdered in a communist prison; Norymberga (Nuremberg, 2006) about a counterintelligence officer who, in the times of the Third Polish Republic, attempts to bring about a "Nuremberg trial," that is, a public tribunal to prosecute the crimes of communism, even at the risk of being convicted himself; Inka (2007), about Danuta Siedzikówna, a military courier and nurse in the post-war resistance movement, imprisoned and tortured under communism; Rozmowy z katem [Conversations with an Executioner, 2007] about Kazimierz Moczarski, a member of the Home Army whom the communists placed in a cell with the commander of the German units tasked with suppressing the Warsaw Ghetto Uprising; Stygmatyczka [The Stigmatist, 2008] about the torment of sister Wanda Broniszewka in communist prisons; Kryptonim Gracz [Codename: Player,

33 These include films like Rysa [Scratch, 2008], by Michał Rosa, Generał Nil [General Nil, dir. Ryszard Bugajski, 2009], Popiełuszko - wolność jest w nas [Popiełuszko: Freedom is Within Us, dir. Rafał Wieczyński, 2009], Róża [Rose, 2001] by Wojciech Smarzowski, Obława [Manhunt, 2012] by Marcin Krzyształowicz, and Pilecki (2015) by Mirosław Krszyszkowski. Another possible addition to this is the television series Czas honoru [Days of Honor, six seasons, broadcast 2008-2014]. 
2008], about a world-famous fencer and a double agent for the Polish Security Service and the CIA; Ziarno zroszone krwia [Grain Drenched in Blood, 2008], about the tragic fate of the fighters in the Home Army, the list could go on.

These plays were not about ideological arguments between opposing worldviews. The government officials portrayed in these dramas have plenty of speaking parts, yet they have nothing to say; they ask many questions, yet they do not seem to be actually interested in learning anything. Their sole purpose is to humiliate, destroy, demean, and torture. The opposite is true of the main characters: they respond to questions curtly, if at all, refusing to give testimony or justify their actions. It is a gallery of lay martyrs whose communication with the communists is exemplary in that they refuse to communicate with them at all. Viewers would be forgiven for thinking that the characters were portrayed not for their diverse life stories, but for their grandiose deaths at the hands of their killers.

The narrative model developed in these plays, based on the juxtaposition of innocent protagonists and immoral oppressors, can also be found in the outdoor theater production Hamlet 44 (directed by Paweł Passini), the radio play 39/89: zrozumieć Polskę ([39/89: Understanding Poland], directed by Łukasz Rostkowski), and the layout of the Warsaw Uprising Museum.

The exhibitions, dramas, and radio plays mentioned (and omitted) above share several distinct ideological assumptions. The first involves history, which is perceived in this instance as a grand theater of events in which geopolitics directs the cast from behind the scenes and politicians play the lead roles, while all the extras are given the choice of assuming either a conformist or heroic stance. From this conviction stems another belief which states that the clash of values is the fullest manifestation of historical processes. Rather than portraying everyday life, these works depict powerful events the outbreak of World War II, the Warsaw Uprising, political assassinations and trials - or pivotal moments in history, providing a chronological framing for the narratives, which in turn enables the illusion of realism. This peculiar game of make believe, one played not just in the cinema and the theater, but also in museums (authentic prison cells, an actual section of wall), serves to contemporize the past. This facilitates compliance between modern-day notions of history - the ones shaped by today's media - and its representation. Lending credence to this tactic is its reliance on the struggle between defenders and attackers: all of the works discussed above depict a world in which the set of historical and moral roles is limited, and thus painfully obvious. One can either be the oppressor or the victim - either beat or be beaten.

The insertion of history into the present is also a way of renewing community by repeating a communal ritual. In this act, we witness a person sacrificing himself in order to secure a future community that will owe its social 
cohesion to the dead heroes. If someone has given his life so that we may be free, then our free lives are burdened with a debt that we may pay by honoring the memory of the fallen and cultivating the values for which they gave their lives.

Therein lay the prosocial power of the turn to community. The works it encompassed not only reminded people of their patriotic duty, but also defined the collective subject in performative terms. It was to be a community that accepted a distinct and limited set of criteria regarding guilt, shame, and pride: guilt defined the oppressors, pride belonged to those who perished, and shame fell upon those who failed to commemorate the heroes, regardless of what those heroes had done in their lives besides dying for their country. The central role of martyred figures in this spectacle challenged the existing pedagogy of shame, as it gave the modern-day depositaries of martyrological truth the right to treat any attempt to shame the nation as an attack on sacred values - an attack that must be repelled. The former slogan - "If you want to be European, you must let yourself be shamed" - was replaced with "If you want to be Polish, you can't let yourself be shamed." A radical change was thus occurring in the approach to the affective economy: while we witnessed a surplus of shame in the 1990s, the end of the first decade of the twenty-first century marked our entrance into the phase of surplus pride.

The shift in attitude necessitated a different perspective on the present. The solutions discussed earlier demanded that the amount of pride inherited be minimized, and further imposed upon the fictional characters the moral duty of remembering collective manifestations of discrimination. Consequently, present-day forms of covert violence such as misogyny, homophobia, antisemitism, and mobbing came to be perceived as extensions of historical forms of violence that had persisted precisely because they had not been subjected to criticism. In the case of art associated with the community turn, on the other hand, artists depicted the flaws of the new system as the result of the disruption of the continuity of patri ot is m. From this point of view, the foundations of Polish democracy and capitalism after 1989 were perceived as corroded, while the corrosion permeating all aspects of life in Poland had resulted from its buckling under the pressure of shame and the blurring of the country's Catholic and heteronormative national identity. To restore order to the country and its social life, this identity would need to be sanctioned once again. This, in turn, meant that any disassembly of the community would need to be put on trial. Thus criticism of the new face of Poland merged with postulations calling for the restitution of collective subjects.

As was the case with the series of television dramas, the apogee once again occurred in the middle of the first decade of the new century. In his 
meaningfully titled novel Nic [Nothing, 2005], Dawid Bieńkowski depicted the rampage of capitalism and its immoral principles as having been caused by disregard for patriotic traditions; their abandonment leads to the loss of both human dignity and national sovereignty, and thus their restoration would help reclaim control over international capital. In contrast to Bieńkowski's perception of the market as the source of the country's crisis of autonomy, in Żywina [MP Żywina, 2008] Rafał Ziemkiewicz associated demoralization (at the local government level) with the blackmail tactics used by former members of the communist regime against their erstwhile collaborators. Bronisław Wildstein was of a similar mind: in the novel Dolina nicości [The Valley of Nothingness, 2008], he presented the delay in "lustration," or the purging of former regime holdovers from political life - which he considered a prerequisite for the rebuilding of the moral code - as a consequence of the long-standing collaboration between the intellectual elites and the communist security services; under the Polish People's Republic, officers would protect their informers, and the secrets thus gained would later guarantee them immunity. In the novel Ukryty [Hidden, 2012], the same writer depicts public attitudes toward the Smolensk disaster and the cross erected on Krakowskie Przedmieście, exposing the demoralizing consequences of the "laughter treatment" employed by various relativists. A community that is incapable of being serious, that is eager to mock national and Catholic values, and that listens to the words of a "shadow" teacher: "We must emerge from under the shadow of the cross. We must emerge into the light of day, where there will be nothing to limit us or show us the way; into open, unlimited space,"34 turns out to be a product of - and a factor in - moral depravity. The image of a crowd jeering at the people praying at the foot of the "Smolensk cross" leads one of the protagonists to conclude the following: "If this unruly mob can humiliate with impunity people who have just come to pray [...]," "[if one is allowed to] destroy something that gives ordinary people a sense of dignity, something that brings them together, that strengthens this nation, then it's no wonder that this country and, by extension, the police operate the way they do."35 Thus the breakdown of the overall order begins with a single person, one who is not afraid to violate inviolable values. His laughter demoralizes the ones who laugh and humiliates those being laughed at. For this reason, in order to rebuild the country, "ordinary people" must be shielded from the laughter and shaming of others. 


\section{Pseudomorphosis}

The pieces of this new puzzle gradually began to connect: the gaps in the al ternative sanctioned shame were filled in with museums, movies, novels, and political initiatives. It relied on the reversal of the existing affective economy for leverage. In its efforts to build a pluralistic and solidary society, Polish culture persuaded Poles in the 1980 s and 1990 s to assume an inconvenient yet heroic stance: "Be proud if you're able to feel shame"; this meant that their pride was to be founded upon the experience of shame when witnessing those who discriminated against the Other, resulting, it was hoped, in a readiness to stand up for the Other today as well. This stance was used at the turn of the century as justification for the disassembly of collective identities, as it was these collective subjects - the nation, single-sex communities, religious communities - that were most frequently responsible for persecuting minorities; this only exacerbated the isolation of individuals, who then had to redefine their own identities and accept the existence of fluid communities assembled for the purpose of solving immediate problems and dissolved soon thereafter. In the second decade of the twenty-first century, and certainly with greater vigor in the wake of the Smolensk disaster, art and politics offered a new collective identity, one that was static and maintained its right to draw pride from history, free of shame for the wrongdoings of its ancestors. This transmutation was accompanied by a new slogan: "Shame on you for not being proud!"

This new sanctioned shame, however, fails to patch the leaks in the sanctioned culture with a new set of reinforcements, and is thus the result of pseudomorphosis rather than metamorphosis, filling in the partial void left by previous articulations of nationalism. Crucially, the program for rebuilding the (patriotic, national, male-centric) community does not abandon the principle of shame itself. In this sense, Jarosław Kaczyński's claim that Poles will never have to be ashamed again is false. The purpose of the new yet anachronistic project is not to dispense with shame but to have it meted out by a different authority and to change its proportions relative to the remaining primary affects. The previous principle of "Minimum pride, maximum shame," is replaced with a new proportion: "Maximum pride, minimum shame."

This reversal was a result of the fact that the economic transformation hijacked the project of pluralism - founded on un-solidarity - and overinvested shame, turning it into the primary source of energy for development. Meanwhile, the affective economy tells us that people strive to minimize their sense of shame. This simple conviction can be found in the key moment of the affective surge, which occured in the first decade of the twenty-first century. In the novel Lód [Ice, 2007], which demythologizes the Polish narratives about Siberian exile, Jacek Dukaj permits the protagonist to state: 
If $[. .$.$] there exists a single principle that governs the behavior of all peo-$ ple, it is the Principle of Lesser Shame. We're capable of consciously striving to cause our own suffering, even our own deaths, but no one strives to cause himself greater shame. Just as water flows down an uneven surface to reach its lowest point, and just as heat escapes a body, so do people pursue the lesser shame in all situations. ${ }^{36}$

Dukaj does not touch upon the events of the first decade of the twentyfirst century in Poland in this monumental work, yet one cannot resist the impression that a bit of the mood of those years had seeped into the novel, compelling it to offer markedly serious commentary on a trivial situation. The resulting question - How can we minimize shame? - was answered with two intricately linked measures: the delegitimization (and later delegalization) of the foundations of emancipatory ethics and the increased exploitation of pride.

The first step involved exposing and emphasizing the social engineering nature of shaming. Rather than applying to a single feature, shame affects a person as a whole. As Ruth Leys writes, "Shame [...] is held to concern not your actions but who you are, that is, your deficiencies and inadequacies as a person [...]."37 It was enough to point out that the past instances of shaming over insufficient emancipation had been an attempt to manipulate Polish society into adopting a penitent stance. As the ethics of the Other were exploited gradually - through a chain of equivalence - by neoliberal politics to create a society of isolated individuals, so the idea of the community reversed this line of reasoning, combining all the aspects of the earlier form of shaming into a uniform pedagogy of shame. In other words, the reversal of the emancipatory ethics of the Other equips society with a new immune system that - as paradoxical as it may sound - attacks the very foreign bodies it itself produces. However, this paradox explains how, upon its return, the "national community" was able to tap an unlimited reservoir of pride. As it turns out, the source of this pride lay not in specific accomplishments as much as in the discovery, made by critical art, that shaming could be used to coerce individuals and groups into submitting to the sanctioned culture. In light of this discovery, the earlier accusations leveled at the nation, accusations regarding violence against the Other, could be dismissed as social engineering. The perversion of this reversal meant that where the emancipatory project placed

36 Jacek Dukaj, Lód (Kraków: Wydawnictwo Literackie, 2007), 103.

37 Ruth Leys, From Guilt to Shame: Auschwitz and After (Princeton and Oxford: Princeton University Press, 2007), 11-12. 
warning signs, the community ethics project saw clues leading to national treasures.

To summarize the paradoxes of Poland's history of shame: first, a noble lesson in the ethics of the Other - a lesson that was supposed to lay the foundations for pride in tolerance exhibited by the nation - deconstructed national pride and revealed a bundle of aggressive xenophobic discourses in Poland's collective identity; in the following decade, critical artworks demystified the hijacking of the project of pluralism by neoliberal politics and revealed the importance of shame in efficiently installing a neoliberal economy. The first stage was intended to elevate the importance of shame, while the second aimed to boost the audience's immune system to the point where they could defend themselves against shame. These two stages could have been synthesized into social solidarity that would accommodate the needs of people deprived of respect and excluded by the market. What resulted instead was a perverse synthesis in which the acquired immunity to market-induced shame was used to reclaim national pride.

For this reason Polish culture is now involved in a war of two sanctioned forms of shame. The first - fragmented, internally inconsistent - emerges from a foundation of ethical concern for the rights of minorities; the second - narrow-minded and hostile towards differences of any kind - appeals to the ethics of majority rights; the former was unable to satisfy the popular need for respect, while the latter exclusively dispenses approval to "its own." The former proposed the Christian principle "Be proud if you're able to feel shame," while the latter hypes the tribal dictum "Shame on you for not being proud!" It appears that as long as the war between these two affective politics rages on, we are doomed to a shortage of respect on the one hand, and a dearth of tolerance on the other.

Perhaps it is therefore worth considering yet another solution, one that could have the motto: "Be proud if you're able to not shame others." Finding a cultural tradition that would foster this stance seems to be an acutely pressing task.

Translation: Arthur Barys 